\title{
Phase I/pharmacokinetic study of CCI-779 in patients with recurrent malignant glioma on enzyme-inducing antiepileptic drugs
}

\author{
Susan M. Chang ${ }^{1}$, John Kuhn ${ }^{2}$, Patrick Wen ${ }^{3}$, Harry Greenberg ${ }^{4}$, David Schiff ${ }^{5}$, Charles Conrad ${ }^{6}$, \\ Karen Fink ${ }^{7}$, H. Ian Robins ${ }^{8}$, Timothy Cloughesy ${ }^{9}$, Lisa De Angelis ${ }^{10}$, Jeffrey Razier ${ }^{10}$, Kenneth \\ Hess $^{6}$, Janet Dancey ${ }^{11}$, Michael D. Prados ${ }^{1}$ for the North American Brain Tumor Consortium \\ and the National Cancer Institute \\ ${ }^{1}$ University of California, San Francisco; ${ }^{2}$ University of Texas, San Antonio; ${ }^{3}$ Dana Farber Cancer Institute; \\ ${ }^{4}$ University of Michigan, ${ }^{5}$ University of Virginia; ${ }^{6}$ MD Anderson Cancer Center $;{ }^{7}$ University of Texas, Southwestern; \\ ${ }^{8}$ Unversity of Wisconsin; ${ }^{9}$ University of California, Los Angeles; ${ }^{10}$ Memorial Sloan Kettering Cancer Center; \\ ${ }^{11}$ Cancer Therapy Evaluation Program, National Cancer Institute
}

Key words: chemotherapy, rapamycin, CCI-779, toxicity

\begin{abstract}
Summary
Objectives: CCI-779 is an ester of the immunosuppressive agent sirolimus (rapamycin) that causes cell-cycle arrest at G1 via inhibition of key signaling pathways resulting in inhibition of RNA translation. Antitumor activity has been demonstrated using cell lines and animal models of malignant glioma. Patients receiving enzyme-inducing anti-epileptic drugs (EIAEDs) can have altered metabolism of drugs like CCI-779 that are metabolized through the hepatic cytochrome $\mathrm{P} 450$ enzyme system. The objectives of this study were to determine the pharmacokinetic profile and the maximum tolerated dose of CCI-779 in patients with recurrent malignant gliioma taking EIAEDs. Study design: The starting dose of CCI-779 was $250 \mathrm{mg}$ intravenously (IV) administered weekly on a continuous basis. Standard dose escalation was performed until the maximum tolerated dose was established. Toxicity was assessed using the National Cancer Institute common toxicity criteria. Results: Two of 6 patients treated at the second dose level of $330 \mathrm{mg}$ sustained a dose-limiting toxicity: grade III stomatitis, grade 3 hypercholesterolemia, or grade 4 hypertriglyceridemia. The maximum tolerated dose was reached at $250 \mathrm{mg}$ IV. Pharmacokinetic profiles were similar to those previously described, but the area under the whole blood concentration-time curve of rapamycin was 1.6 fold lower for patients on EIAEDs. Conclusions: The recommended phase II dose of CCI 779 for patients on enzyme-inducing antiepileptic drugs is $250 \mathrm{mg}$ IV weekly. A phase II study is ongoing to determine the efficacy of this agent.
\end{abstract}

\section{Introduction}

Treatment options are limited for patients with malignant glioma recurring despite radiation and adjuvant chemotherapy with either a nitrosourea or temozolomide [1]. Recent advances in the understanding of molecular and cytogenetic pathways involved in gliomagenesis, tumor growth, and invasion have led to the rational targeting of aberrant molecular pathways. A significant proportion of glioblastoma mul- tiforme (GBM) have altered PTEN gene-suppression activity [2], which results in the increased activity of the phosphotidylinositol 3-kinase (PI3K)/Akt pathway. This in turn activates the mammalian target of rapamycin (mTOR), thereby increasing translation of a number of key proteins required for cell-cycle progression. The presence of PTEN gene alterations and the subsequent activation of the PI3K/Akt/mTOR pathway have been associated with poor prognosis in anaplastic astrocytoma (AA), anaplastic oligodendroglioma, and 
GBM [3-5]. Restoration of PTEN function or targeting of the components of the PI3K/Akt/mTOR pathways can result in cell-cycle arrest, apoptosis, or reduced tumorigenicity and are rational targets for clinical evaluation.

One agent that targets the mTOR pathway is CCI-779, a dihydroxymethyl propionic acid ester of the immunosuppressive agent sirolimus (rapamycin, Rapamune $\left.{ }^{\circledR}\right)$. Rapamycin, a macrolide originally isolated from Streptomyces hygroscopicus, is a potent immunosuppressant, and like other natural immunosuppressants such as cyclosporin A and FK-506 interacts with signal-transduction systems that operate in both normal $T$ cells and tumor cells. These agents bind to a ubiquitous family of proteins known as immunophilins, inhibiting their enzymatic activity. Rapamycin binds to one of these proteins to form a complex that interacts with mTOR, which results in cell-cycle arrest via inhibition of RNA translation [6-8].

During development and evaluation of rapamycin and its analogs, physiochemical and pharmaceutical factors were considered in the selection of an optimum derivative. The National Cancer Institute, in collaboration with Wyeth Ayerst, examined several derivatives of rapamycin and selected CCI-779 for further development based on in vitro and in vivo data. CCI-779 is lipid soluble and inhibits the growth of a number of human tumor lines in nude mouse models including glioblastoma. In addition, 2 preclinical studies reported the inhibition of growth of PTEN-mutant tumor cells by CCI-779, both in vitro and in the PTEN \pm mouse model [9-11]. Clinical studies in patients with other solid tumors demonstrated that CCI-779 was well tolerated, with the major adverse events being myelosuppression, cutaneous toxicity, nausea/vomiting, diarrhea, and hypertriglyceridemia $[6,12]$. The dose of $250 \mathrm{mg}$ once weekly as a flat dosing schedule was selected for further study based on therapeutically achieved drug levels. Based on the preclinical and clinical data outlined above there was an interest in evaluating this novel agent in patients with malignant glioma.

There is increasing evidence that brain-tumor patients receiving $\mathrm{P} 450$ enzyme-inducing anti-epileptic drugs (EIAEDs) have markedly altered pharmacokinetics, resulting in accelerated drug metabolism. CCI779 and rapamycin are substrates for the cytochrome $\mathrm{P} 450$ isoenzyme 3A4. It is likely that the patients taking EIAEDs would have increased drug metabolism and would tolerate a higher dose than patients who are not taking these agents.
Patients on EIAEDs were enrolled in the phase I component of this study with dose escalations in initial cohorts of 3 with standard criteria for escalation. The primary objectives of this phase I study were to establish the maximum tolerated dose of CCI-779 in patients with malignant glioma who are taking EIAEDs and to define the safety profile of CCI-779 administered weekly. Pharmacokinetic (PK) analyses were performed to evaluate the CCI-779 and rapamycin concentrations and clearance characteristics and to compare the parameters of exposure to those of patients not on EIAEDs (enrolled in phase II of this trial). The phase II component for the EIAED group will be initiated based on the maximum tolerated dose (MTD) established in this phase I study. We report on the results of the phase I trial in patients on EIAEDs and on the pharmacokinetic components of the study.

\section{Methods}

\section{Patient eligibility}

Patients at least 18 years of age participated if they had histopathologically confirmed recurrent malignant glioma as shown on neuro-imaging. Participating patients had relapsed after prior radiation therapy with an interval of at least 4 weeks from treatment with radiotherapy, and had not received treatment for more than 3 prior relapses. Patients had a Karnofsky Performance Status of at least 60 with an estimated survival of greater than 8 weeks. Their hematologic, renal, and hepatic status was within the normal range, levels of cholesterol were less than $350 \mathrm{mg} / \mathrm{dl}$, and levels of triglyceride were less than $400 \mathrm{mg} / \mathrm{dl}$, respectively. No exclusions were made based on gender, race, minority status, or economic status. Female patients were not pregnant or nursing, and all patients (both men and women) agreed to practice birth control during and for 3 months after the study was completed. Patients or their surrogates signed a Committee on Human Research institutionally approved consent form. Patients did not have any serious intercurrent illness or disease that obscured or altered drug metabolism.

\section{Study design}

Patients were treated with CCI-779 as a 30-minute IV infusion weekly with no rest period required. For the purpose of evaluation, a cycle was defined as every 4 weeks. During the 8 th week of treatment patients 
Table 1. Enzyme-inducing and non-enzyme-inducing anti-epileptic drugs

\begin{tabular}{ll}
\hline $\begin{array}{l}\text { EIAEDs } \\
\text { Carbamazepine } \\
\text { Oxcarbazepine }\end{array}$ & (Tegretol, Tegretol XR, Carbatrol) \\
Phenytoin & (Dileptal) \\
Fosphenytoin & (Cerebyx) \\
Phenobarbital & \\
Primidone & (Mysoline) \\
Non-EIAEDs & \\
Valproic acid & (Depakote, Depakene) \\
Gabapentin & (Neurontin) \\
Lamotrigine & (Lamictil) \\
Topriamate & (Topamax) \\
Tiagabine & (Gabatril) \\
Zonisamide & (Zonegran) \\
Levatriacetam & (Keppra) \\
Clonazepam & (Klonopin) \\
Clonozam & (Frisium) \\
\hline
\end{tabular}

underwent clinical and radiographic tumor re-staging. Determination of tumor status was made using standard criteria [13]. Therapy with CCI-779 was continued as long as the tumor was stable or smaller in size and the patient was clinically stable or improved. Treatment continued indefinitely as long as there were no unacceptable toxicities, patient refusal to continue participation, or tumor progression. Patients receiving EIAEDs were treated at an initial dose level of $250 \mathrm{mg}$ IV weekly, and dose levels of 330, 440, 585, and $780 \mathrm{mg}$ were defined for escalation. Table 1 outlines the drugs categorized as EIAEDs and non-EIAEDs.

\section{Definition of the maximum tolerated dose}

The maximum tolerated dose was based on the tolerability observed during the first 4 weeks of treatment. Standard phase I dose escalations were planned among groups of 3 patients, with an additional 3 patients added at the first indication of dose-limiting toxicity. The maximum tolerated dose of CCI-779 was that dose at which fewer than one-third of patients experienced a dose limiting toxicity, i.e., the dose at which $0 / 3$ or $1 / 6$ patients experienced a dose-limiting toxicity with the next higher dose having at least $2 / 3$ or $2 / 6$ patients who experienced a dose-limiting toxicity.

\section{Toxicity assessment}

Toxicities were graded according to the NCI Common Toxicity Criteria scale (CTC Version 2.0). If multiple toxicities were seen, the presence of a dose-limiting toxicity was based on the most severe toxicity experienced. A dose-limiting toxicity was defined as any of the following events occurring during the first 4-week course of treatment of CCI-779 and attributable to the study drug: any grade 4 hematologic toxicity; any nonhematologic grade 3 toxicity; or failure to recover from toxicities to be eligible for re-treatment with CCI-779 within 2 weeks of the last dose of CCI-779 treatment.

\section{Pharmacokinetic evaluation}

Sample collection. Whole blood $(7 \mathrm{ml})$ was collected in EDTA-containing tubes at each of the following times: baseline (prior to infusion); end of infusion; and $0.5,1,1.5,2,3,5,8$, and 24 hours post-administration. Baseline samples were also obtained on course 1 day 8 and course 2 day 1 . The whole blood was transferred into 2 polypropylene tubes ( 1 for CCI-779 determination and 1 for rapamycin) and stored at $-70^{\circ} \mathrm{C}$ until analyzed. Whole blood was selected as the biological matrix for analysis due to CCI-779's and rapamycin's preferential distribution into red blood cells and more limited storage stability in plasma.

\section{Analytical methods}

For the analysis of CCI-779 and rapamycin, 2 separate high performance liquid chromatography (HPLC) with electrospray ionization mass spectrometry (LC/ESIMS) assays were developed and validated. CCI-779 and the deuterated (d7) CCI-779 internal standard (IS) as well as rapamycin and its IS (desmethoxyrapa) were obtained from Wyeth-Ayerst Research (Monmouth Junction, NJ) through Dr. Janet Dancey (Div. Cancer Treatment Diagnosis Ctr., NCI).

CCI-779 and rapamycin were isolated from whole blood by liquid-liquid extraction. Briefly, $850 \mu \mathrm{l}$ of whole blood was spiked with $100 \mu \mathrm{l}(50 \mathrm{ng})$ of the appropriate IS followed by the addition of $7 \mathrm{ml}$ of 1-chlorobutane. After circular rotation for 1 hour, the samples were centrifuged $\left(10^{\circ} \mathrm{C}\right.$ at $3000 \mathrm{RPM} \times$ $15 \mathrm{~min})$ and placed in a $-80^{\circ} \mathrm{C}$ freezer for $30 \mathrm{~min}$ utes. The organic layer was separated and evaporated to dryness under a gentle stream of nitrogen in a $35^{\circ} \mathrm{C}$ water bath and reconstituted with $100 \mu \mathrm{l}$ of mobile phase consisting of $0.05 \mathrm{mM}$ sodium acetate and $0.002 \%(\mathrm{~V} / \mathrm{V})$ acetic acid in methanol pumped at a flow rate of $0.2 \mathrm{ml} / \mathrm{min}$. Following re-centrifugation for 15 min, $20 \mu \mathrm{l}$ of sample was injected using a Hewlett Packard series II 1090 HPLC (Hewlett Packard, Palo Alto, CA). Separation of CCI-779 was accomplished 
by using a Waters C18 Symmetry ${ }^{\mathrm{TM}}$ column $(3.5 \mu \mathrm{m}$, $21 \times 50 \mathrm{~mm})$ preceded by a Waters Sentry ${ }^{\mathrm{TM}} \mathrm{C} 18$ guard column $(3.5 \mu \mathrm{m}, 2.1 \times 10 \mathrm{~mm})$ (Waters Corporation, Milford, MA). A Phenomenex C6 column ( $3 \mu \mathrm{m}$, $150 \times 200 \mathrm{~mm}$ ) preceded by a Phenomenex Security ${ }^{\mathrm{TM}}$ C5 guard column ( $3 \mu \mathrm{m}, 2 \times 4 \mathrm{~mm}$ ) (Phenomenex, Torrance, CA) was used for the separation of rapamycin. After separation, the sample was directly flushed into the API electrospray interface (Finnigan LCQTM spectrometer (MS), San Jose, CA). The MS settings were: sheath gas (N2) flow rate-66 arb; capillary voltage $-23 \mathrm{~V}$; auxiliary gas (He) flow rate $-27 \mathrm{arb}$; capillary temperature $-230^{\circ} \mathrm{C}$; spray voltage $-5.5 \mathrm{kV}$; and tubes lens offset $-10 \mathrm{~V}$.

In the MS/MS mode, the collision energy was $42 \%$. For peak identification, full-scan mass spectra were acquired in the positive ion mode. The MS/MS scan range for CCI-779 was 950-1100, and 600-1100 for rapamycin. Selected ion monitoring (SIM) was used for the determination of the sodium adducts $[\mathrm{M}+$ $\mathrm{Na}]$ and the compound's respective fragment ion: $\mathrm{CCI}-$ $779(\mathrm{~m} / \mathrm{z} 1052.3 \rightarrow 1020.4)$, d7-CCI-779 (m/z 1057.3 $\rightarrow$ 1027.4), and rapamycin $(\mathrm{m} / \mathrm{z} 936.5 \rightarrow 904.3)$, desmethoxy rapamycin $(\mathrm{m} / \mathrm{z} 906.4 \rightarrow 874.4)$. Data acquisition and integration of the chromatograms were performed using Xcaliber ${ }^{\mathrm{TM}}$ software (Version 1.0, Finnigan, San Jose, CA). The chromatographic data were analyzed by linear least square regression with a weighting factor of $1 / \times 2$ generating an eight-point calibration curve of area ratios for CCI-779 and rapamycin. Unknown concentrations were determined by reverse prediction against the standard curve. The calibration curves for both CCI-779 and rapamycin were linear $(\mathrm{R} 2>0.99)$ over the range from 6.58 to $526.5 \mathrm{ng} / \mathrm{ml}$. End-of-infusion samples for CCI-779 were diluted 1:100 into the linear range of the calibration curve. Each sample was analyzed in duplicate. Samples were repeated if the variation between samples was greater than $16 \%$. The interday precision (CV) for CCI-779 was $1.7,4.38$, and $10.5 \%$, respectively for the low, medium, and high quality control (QC) samples. The interday accuracy (bias) was within \pm 4.7 . The interday precision for rapamycin was $12.21,6.1$, and $6.73 \%$, respectively for the low, medium, and high QC samples. The interday accuracy was within $\pm 5.9 \%$.

\section{Pharmacokinetic analyses}

CCI-779 and rapamycin whole blood concentrations were analyzed by non-compartmental methods. The time intervals relative to the start of the CCI-779 infusion and the actual sample times were used for the determination of time to peak (tmax) and the area under the whole blood concentration-time curves (AUC). Peak concentrations (CPmax) were determined by inspection of each individual's whole blood concentrationversus-time curve. Elimination rate constants were estimated by linear regression of the last 2 data points on the terminal log linear portion of the concentrationtime curve. Terminal half-lives $(t 1 / 2)$ were calculated by dividing 0.693 by the elimination rate constants. The AUC was calculated using the linear trapezoidal rule up to the last measurable data point (for $\mathrm{AUC0}-24$ ), then extrapolated to infinity (AUC). The systemic clearance (CL) for CCI-779 was determined by dividing the dose by the AUC. A metabolic ratio estimated as the ratio of the $\mathrm{AUC}_{\text {rap }}$ to the $\mathrm{AUC}_{\mathrm{CCI}}$ was used as a measure of the relative extent of conversion of CCI-779 to rapamycin.

\section{Results}

\section{Clinical results}

Twelve patients ( 6 males/ 6 females) were enrolled. Median age was 52 years (range 39-63 years) and the median Karnofsky Performance Scale was 90. Patient characteristics are shown in Table 2. Two dose levels were evaluated. At the $250 \mathrm{mg}$ level, 2 patients were on single-agent dilantin, 1 on tegretol, 1 on Phenobarbital, and 2 on combination agents ( 1 on Phenobarbital, Keppra, and dilantin and 1 on Trileptal and Neurontin). At the $330 \mathrm{mg}$ dose level, all patients were on monotherapy -3 on dilantin, 2 on tegretol, and 1 on carbatrol. There was $1 / 6$ dose-limiting toxicity at the first dose level of $250 \mathrm{mg}$ consisting of grade III hypertriglyceridemia. Two of 6 patients treated at the second dose level of $330 \mathrm{mg}$ sustained a dose-limiting toxicity: 1 patient developed grade III stomatitis and another grade 3 hypercholesterolemia as well as grade 4 hypertriglyceridemia that required a delay of more than 2 weeks before retreatment (Table 3 ). The maximum tolerated dose was therefore established at $250 \mathrm{mg}$ IV weekly for patients on enzyme-inducing antiepileptic agents. There is limited information on the toxicity profiles on the 12 patients in this study beyond the first course. There were no grade IV toxicities seen and the grade III toxicities are shown in Table 4 with information provided based on the course number. The phase II study will provide more information on cumulative and long-term toxicity. 
Table 2. Patient characteristics $(n=12)$

\begin{tabular}{lll}
\hline $\begin{array}{l}\text { Age, years } \\
\text { Median } \\
\text { Range }\end{array}$ & 52 & \\
\hline Characteristic & $39-63$ & \\
\hline Sex & No. & $(\%)$ \\
$\quad$ Male & & \\
Female & 6 & 50 \\
Karnofsky Performance Scale & 6 & 50 \\
70 & 3 & 25 \\
80 & 2 & 17 \\
90 & 7 & 58 \\
Histology & & \\
$\quad$ Anaplastic astrocytoma & 3 & 25 \\
$\quad$ Glioblastoma multiforme & 9 & 75 \\
Therapy for prior relapses & & \\
1 & 6 & 50 \\
2 & 6 & 50 \\
\hline
\end{tabular}

Table 3. Toxicity observed in the phase I study $(n=12)$, using the National Cancer Institute Common Toxicity Grading System

\begin{tabular}{|c|c|c|}
\hline Dose level & $n$ & Dose limiting toxicity \\
\hline $250 \mathrm{mg}$ & 6 & 1 grade III hypertriglyceridemia \\
\hline $330 \mathrm{mg}$ & 6 & $\begin{array}{l}1 \text { grade III stomatitis } \\
1 \text { grade III hypercholesterolemia, grade IV } \\
\text { hypertriglyceridemia, and delay of }>2 \\
\text { weeks before retreatment }\end{array}$ \\
\hline
\end{tabular}

Table 4. Grade III toxicities seen beyond course 1 for the 2 cohorts

\begin{tabular}{lcl}
\hline 250 mg dose level cohort & $n$ & $\begin{array}{l}\text { Grade III toxicity } \\
\text { Edema } \\
\text { Course no. }\end{array}$ \\
2 & 1 & $\begin{array}{l}\text { Rash } \\
\text { Fatigue }\end{array}$ \\
9 & $n$ & $\begin{array}{l}\text { Grade III toxicity } \\
\text { Headache* } \\
\text { Hypophosphatemia* }\end{array}$ \\
& 130 mg dose level cohort \\
Course no. & 1 &
\end{tabular}

*These toxicities were experienced after a dose reduction from 330 to $250 \mathrm{mg}$ for the second course.

In this small cohort of 12 patients, no partial or complete responses were observed. There were $4 / 6$ patients in the $250 \mathrm{mg}$ dose level with stabilization of their disease, with median progression-free survival of 10 weeks. The efficacy of this agent is being evaluated in the ongoing phase II study in patients with recurrent malignant glioma on and off enzyme-inducing antiepileptic agents.

\section{Pharmacokinetic results}

A typical whole blood concentration-versus-time curve at the $250 \mathrm{mg}$ dose level for CCI-779 and rapamycin is displayed in Figure 1. CCI-779 was rapidly converted to rapamycin. The pharmacokinetic results for CCI779 and rapamycin are shown in Table 5. Comparison of the pharmacokinetic parameters at the $250 \mathrm{mg}$ dose level between 2 groups (non-EIAEDs vs. EIAEDs; patients not on EIAEDs were being treated on a concurrent phase II study) showed no difference except for the AUCs for rapamycin. The rapamycin AUC was 1.6-fold lower for patients receiving EIAEDs. A proportionate increase in blood concentrations or AUCs was not observed in the EIAED group for either CCI779 or rapamycin when escalating the dose from 250 $330 \mathrm{mg}$. In fact it was lower for CCI-779 at the higher dose level versus the lower dose. Although a pharmacogenetic explanation may account for this variability, it is probably best explained by a random finding in a small number of patients with only 1 increment for comparison. Baseline levels for CCI-779 on course 1 day 8 or course 2 day 1 were nondetectable. In contrast, baseline levels for rapamycin were observed in the majority of patients. The concomitant medications that patients received that may also be metabolized by the CYP3A4 system were reviewed. Seven out of 12 patients were on concomitant steroids ( 3 in the 250 dose-level group and 4 in the 330 dose-level group, respectively). Two patients in the 250 cohort were on diflucan and 1 was on metaclopramide.

Pharmacokinetic profiles for patients in the phase II component of the study continue to be assessed.

\section{Discussion}

The insight into the relevance of the P13K/Akt/mTOR pathway in the proliferation of tumors has generated several rational targeted therapies. Wortmannin and LY294002 are inhibitors of PI3K, while rapamycin, RAD001, and CCI-779 inhibit the activity of mTOR [14-16]. CCI-779, an ester of rapamycin, was selected for further evaluation based on its more favorable pharmaceutical profile over other clinical leads evaluated. Based on preclinical data of CCI-779 and its potential anti-glioma activity, the efficacy of this agent is being evaluated in a concurrent phase II study in patients with recurrent malignant glioma who are not on concomitant antiepileptics that may induce the CYP450 hepatic 
Table 5. Pharmacokinetic Parameters of CCI-779 and Rapamycin

\begin{tabular}{|c|c|c|c|c|c|c|c|c|c|c|c|c|c|}
\hline \multirow[b]{2}{*}{$\begin{array}{l}\text { Means } \\
( \pm \mathrm{SD})\end{array}$} & \multicolumn{7}{|c|}{ CCI-779 } & \multicolumn{6}{|c|}{ Rapamycin } \\
\hline & $\begin{array}{l}\text { Dose } \\
(\mathrm{mg})\end{array}$ & $\begin{array}{l}C_{\max }{ }^{a} \\
(\mu \mathrm{g} / \mathrm{ml})\end{array}$ & $\begin{array}{l}t 1 / 2^{\dagger} \\
(\mathrm{h})^{b}\end{array}$ & $\begin{array}{l}\mathrm{AUC}^{c} \\
(\mu \mathrm{g} \times \mathrm{h} / \mathrm{ml})\end{array}$ & $\begin{array}{l}\mathrm{CL}^{d} \\
(\mathrm{~L} / \mathrm{h})\end{array}$ & $\begin{array}{l}\mathrm{CL} \\
\left(\mathrm{L} / \mathrm{h} / \mathrm{m}^{2}\right)\end{array}$ & $\begin{array}{l}\mathrm{V}_{\mathrm{dss}}{ }^{e} \\
(\mathrm{~L})\end{array}$ & $\begin{array}{l}C_{\max } \\
(\mathrm{ng} / \mathrm{ml})\end{array}$ & $\begin{array}{l}t 1 / 2^{\dagger} \\
\text { (h) }\end{array}$ & $\begin{array}{l}\mathrm{AUC} \\
(\mu \mathrm{g} \times \mathrm{h} / \mathrm{ml})\end{array}$ & $\begin{array}{l}\text { AUC ratio } \\
\text { Rap:CCI }\end{array}$ & $\begin{array}{l}\text { Trough } 24 \mathrm{~h} \\
\text { Post (ng/ml) }\end{array}$ & $\begin{array}{l}\text { Baseline } \\
168 \mathrm{~h} \mathrm{ng} / \mathrm{ml}\end{array}$ \\
\hline $\begin{array}{l}\text { Group } \\
\mathrm{A}^{*} \\
(n=4)\end{array}$ & 250 & $\begin{array}{c}6.2 \\
(5.7)\end{array}$ & $\begin{array}{l}9.0 \\
(3.8)\end{array}$ & $\begin{array}{l}6.1 \\
(2.9)\end{array}$ & $47(18)$ & $\begin{array}{l}24 \\
(8.9)\end{array}$ & $\begin{array}{l}308.68 \\
(175)\end{array}$ & $\begin{array}{l}310 \\
(120)\end{array}$ & $\begin{array}{l}50 \\
(23)\end{array}$ & $\begin{array}{l}15.1 \\
(3.7)\end{array}$ & $\begin{array}{c}2.8 \\
(1.3)\end{array}$ & $\begin{array}{l}137 \\
(24)\end{array}$ & $\begin{array}{l}15 \\
(6.9)\end{array}$ \\
\hline $\begin{array}{l}\text { Group } \\
\mathrm{B}^{* *} \\
(n=3)\end{array}$ & 250 & $\begin{array}{c}5.2 \\
(4.9)\end{array}$ & $\begin{array}{l}8.5 \\
(2.7)\end{array}$ & $\begin{array}{l}5.7 \\
(2.7)\end{array}$ & $\begin{array}{l}50 \\
(20)\end{array}$ & $\begin{array}{l}25 \\
(7.0)\end{array}$ & $\begin{array}{l}671.10 \\
(307\end{array}$ & $\begin{array}{l}182 \\
(45)\end{array}$ & $\begin{array}{l}35 \\
(13)\end{array}$ & $\begin{array}{l}9.3 \\
(2.2)\end{array}$ & $\begin{array}{c}1.9 \\
(0.9)\end{array}$ & $\begin{array}{l}111 \\
(18)\end{array}$ & $\begin{array}{l}7 \\
(n=1)\end{array}$ \\
\hline $\begin{array}{l}\text { Group } \\
\mathrm{B}(n=3)\end{array}$ & 330 & $\begin{array}{c}2.2 \\
(0.9)\end{array}$ & $\begin{array}{l}10.0 \\
(3.4)\end{array}$ & $\begin{array}{l}3.3 \\
(0.4)\end{array}$ & $\begin{array}{l}103 \\
(13)\end{array}$ & $\begin{array}{l}48 \\
(2.6)\end{array}$ & $\begin{array}{l}781.61 \\
(401)\end{array}$ & $\begin{array}{l}278 \\
(105)\end{array}$ & $\begin{array}{l}24 \\
(5.5)\end{array}$ & $\begin{array}{l}9.1 \\
(1.8)\end{array}$ & $\begin{array}{c}2.8 \\
(0.6)\end{array}$ & $\begin{array}{l}132 \\
(33)\end{array}$ & $\begin{array}{l}13 \\
(n=1)\end{array}$ \\
\hline
\end{tabular}

${ }^{*}$ non-EIAEDs ${ }^{f} ;{ }^{* *}$ EIAEDs; ${ }^{\dagger}$ Harmonic mean.

${ }^{a} C_{\max }$ : maximum concentration; ${ }^{b} t 1 / 2$ : half life; ${ }^{c} \mathrm{AUC}$ : area under the curve; ${ }^{d} \mathrm{CL}$ : clearance; ${ }^{e} \mathrm{~V}_{\mathrm{dss}}$ : volume of distribution; ${ }^{f}$ EIAEDs: enzyme inducing anti-epileptic agents.

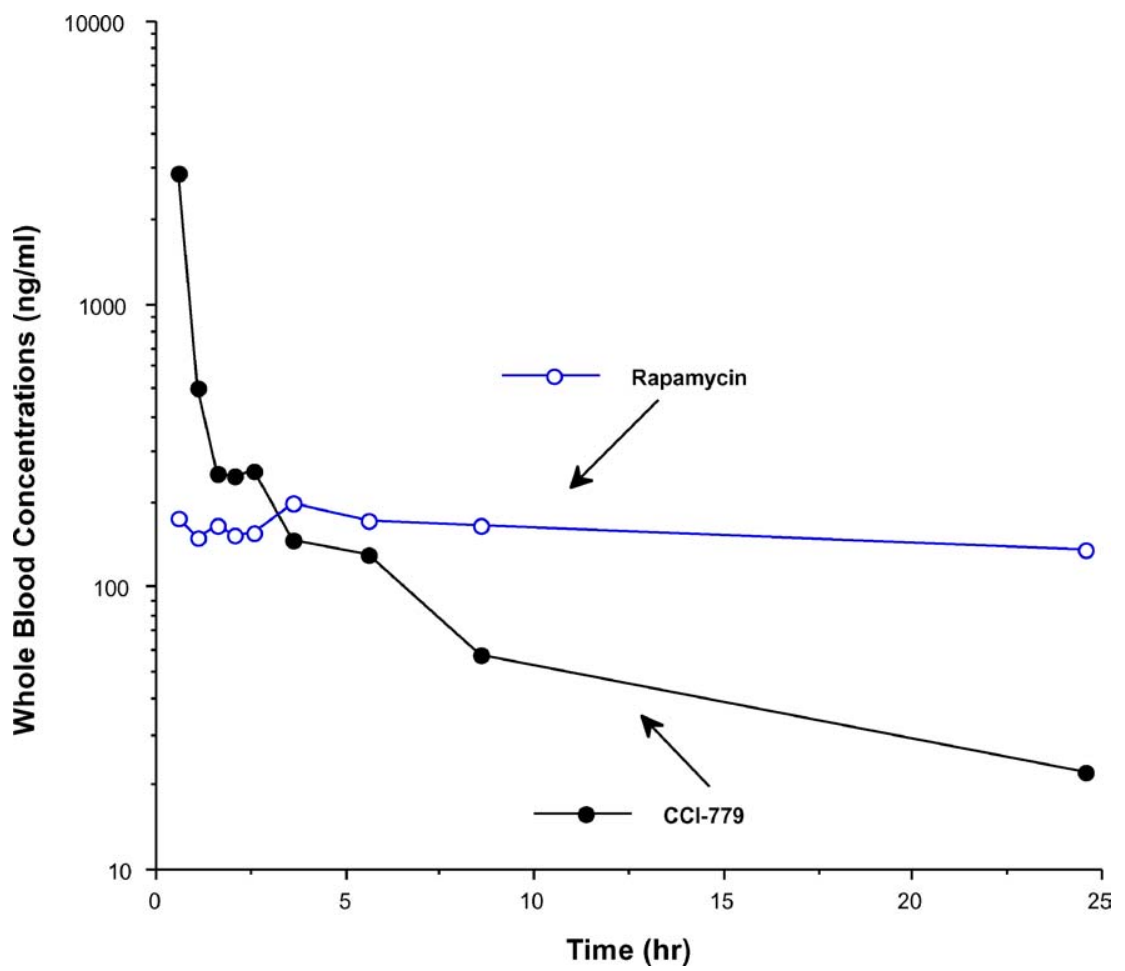

Figure 1. Typical whole blood concentration-time curve for CCI-779 and rapamycin following the administration of CCI-779 IV over 30 minutes.

enzyme system. Because CCI-779 and rapamycin are metabolized by this enzyme system and concurrent use of these agents may result in increased clearance of CCI-779, we sought to establish the appropriate phase II dose in patients on enzyme-inducing agents. The general observation of a higher tolerated dose in patients on enzyme-inducing antiepileptic agents was es- tablished for other agents used in the therapy of malignant glioma including the chemotherapeutic agents paclitaxel [17] and irinotecan [18] and the farnesyl transferase inhibitor R115777 [19].

In this phase I study, the maximum tolerated dose of CCI-779 in patients on enzyme inducing agents was established at $250 \mathrm{mg}$ IV weekly with dose-limiting 
toxicities consisting of previously observed but manageable elevation of lipid profile, hypophosphotemia, and anemia. The dose selected in the phase II study for glioma patients not on EIAEDs was $250 \mathrm{mg}$, which had to be decreased to $170 \mathrm{mg}$ because of excessive toxicity, mainly stomatitis. The recommended phase II dose of $250 \mathrm{mg}$ for the patients with glioma on EIAEDs is therefore higher than for those not on EIAEDs. For non-glioma patients studied during other trials, preliminary results for the weekly dose schedule showed that doses less than $220 \mathrm{mg} / \mathrm{m} 2 /$ week were feasible [20], and that at the $250 \mathrm{mg}$-weekly dose toxicities were usually grade II in nature [21, 22]. Final reports of these studies are not yet available.

Escalation beyond the starting dose of $250 \mathrm{mg}$ was not tolerated. This finding may not be surprising given the results of the pharmacokinetic data generated from this study. CCI-779 is converted to rapamycin that is itself metabolized by the same CYP450 enzyme system and can be associated with its own spectrum of side effects. The toxicities encountered therefore may have reflected the additive and/or cumulative effects of both drugs. The mean whole blood terminal disposition half-life for rapamycin is reportedly $82 \pm 12$ hours [23]. The terminal half-life for rapamycin observed in our study averaged $42 \pm 24$ hours. The sampling schedule for our trial extended only to 24 hours postdose and the number of patients evaluated was small. Therefore, our observed rapamycin half-life is probably underestimated. This is supported by the significant levels of rapamycin remaining at 24 hours post-dose and detection of baseline levels prior to the next weekly dose. The low baseline concentrations of rapamycin would not be expected to result in any significant accumulation from week to week. More detailed pharmacokinetic data will be generated in the phase II study.

Although dose escalation was not possible because of side effects, the conversion of CCI-779 to rapamycin is of clinical significance. The administration of CCI-779 intravenously allows for the delivery of a potentially active antitumor agent that is also converted to another active antitumor agent. Eshleman et al. showed that incubation with $100 \mathrm{mM}$ of CCI-779 $(91.4 \mathrm{ng} / \mathrm{ml})$ for 72 hours significantly inhibited the proliferation of U87 malignant glioma cells [24]. Both the parent drug and its metabolite have a spectrum of side effects, some of which overlap. This paradigm is distinct from the administration of a classic inactive "pro-drug" that requires activation or the administra- tion of an active agent that is subsequently degraded to an inactive form. This emphasizes that the subsequent early clinical evaluation of new agents must take into consideration not only the pharmacokinetic data but also the biochemical properties of the agent and its metabolites. One of the secondary objectives of the phase II study will be the assessment of toxicity and tolerability of this agent in a larger patient population. Because of the risk of immunosuppression and the common concomitant use of steroids, opportunistic infections may be seen at a higher rate in phase II studies. A recent pubication by Peralba et al. suggests the possible use of p70(s6) kinase activity as a surrogate marker of drug activity [25]. Further work evaluating this marker needs to be done. In addition, there may be a role for combination CCI-779/standard cytotoxic chemotherapy in the management of glioma.

\section{Conclusions}

The maximum tolerated dose of CCI-779 administered IV on a weekly intravenous schedule to patients with recurrent malignant glioma on enzyme inducing antiepileptic drugs was $250 \mathrm{mg}$. Agents such as paclitaxel and irinotecan that are metabolized via the CYP450 pathway have altered clearance and the established phase II dose of these agents for patients on enzyme-inducing agents was substantially higher than for those who were not. In contrast, although CCI-779 is also metabolized via this pathway, its conversion to rapamycin, which not only has possible antitumor effect but also potential toxicity, may have precluded escalation beyond the level seen for those patients who were not taking enzyme-inducing agents. This emphasizes the importance of biochemical information as well as the pharmacokinetic and pharmacodynamic studies that need to be considered in early clinical studies in order to characterize the effect of the agent and its metabolites on patients. The phase II study in patients with recurrent malignant glioma on and off enzyme-inducing antiepileptic drugs is ongoing to further characterize the pharmacokinetics, safety profile, and efficacy of CCI-779.

\section{Acknowledgments}

The authors would like to acknowledge the following sources of support: 


\begin{tabular}{lll}
\hline Institution & $\begin{array}{l}\text { Member/affiliate } \\
\text { grant number }\end{array}$ & $\begin{array}{l}\text { GCRC grant } \\
\text { number }\end{array}$ \\
\hline $\begin{array}{l}\text { University of California, } \\
\text { San Francisco }\end{array}$ & $\begin{array}{l}\text { NABTC \# CA62399 } \\
\text { Member \# CA62422 }\end{array}$ & M01-RR00079 \\
$\begin{array}{c}\text { University of Texas, M.D. } \\
\text { Anderson Cancer Center }\end{array}$ & CA62412 & CA16672 \\
$\begin{array}{l}\text { Dana Farber Cancer Center } \\
\text { University of Texas, } \\
\quad \text { Southwestern Medical Center }\end{array}$ & C01CA62407-08 & N/A \\
$\begin{array}{l}\text { University of Texas, } \\
\text { San Antonio }\end{array}$ & CA62426 & M01-RR00633 \\
$\begin{array}{l}\text { University of California, } \\
\text { Los Angeles }\end{array}$ & U01 CA62399 & N/A \\
$\begin{array}{l}\text { \#022330 for } \\
\text { University of Michigan }\end{array}$ & NABTC98-03 only & \\
$\begin{array}{l}\text { Memorial Sloan-Kettering } \\
\text { Cancer Center }\end{array}$ & 5-U01CA62399 & M01-RR00042 \\
$\begin{array}{l}\text { University of Wisconsin } \\
\text { Hospital }\end{array}$ & U01CA62421-08 & M01 RR03186 \\
\hline
\end{tabular}

The authors thank Sharon Reynolds, Department of Neurological Surgery, University of California San Francisco for editorial support.

\section{References}

1. Wong ET, Hess KR, Gleason MJ, Jaeckle KA, Kyritsis AP, Prados MD, Levin VA, Yung WK: Outcomes and prognostic factors in recurrent glioma patients enrolled onto phase II clinical trials. J Clin Oncol 17: 2572, 1999

2. Knobbe CB, Merlo A, Reifenberger G: Pten signaling in gliomas. Neuro-oncol 4: 196-211, 2002

3. Sasaki H, Zlatescu MC, Betensky RA, Ino Y, Cairncross JG, Louis DN: PTEN is a target of chromosome 10q loss in anaplastic oligodendrogliomas and PTEN alterations are associated with poor prognosis. Am J Pathol 159: 359-367, 2001

4. Sano T, Lin H, Chen X, Langford LA, Koul D, Bondy ML, Hess KR, Myers JN, Hong YK, Yung WK, Steck PA: Differential expression of MMAC/PTEN in glioblastoma multiforme: Relationship to localization and prognosis. Cancer Res 59: 18201824, 1999

5. Smith JS, Tachibana I, Passe SM, Huntley BK, Borell TJ, Iturria N, O'Fallon JR, Schaefer PL, Scheithauer BW, James CD, Buckner JC, Jenkins RB: PTEN mutation, EGFR amplification, and outcome in patients with anaplastic astrocytoma and glioblastoma multiforme. J Natl Cancer Inst 93: 1246-1256, 2001

6. Hidalgo M, Rowinsky EK: The rapamycin-sensitive signal transduction pathway as a target for cancer therapy. Oncogene 19: 6680-6686, 2000

7. Chen J, Fang Y: A novel pathway regulating the mammalian target of rapamycin (mTOR) signaling. Biochem Pharmacol 64: 1071-1077, 2002

8. Schmelzle T, Hall MN: TOR, a central controller of cell growth. Cell 103: 253-262, 2000
9. Geoerger B, Kerr K, Tang CB, Fung KM, Powell B, Sutton LN, Phillips PC, Janss AJ: Antitumor activity of the rapamycin analog CCI-779 in human primitive neuroectodermal tumor/medulloblastoma models as single agent and in combination chemotherapy. Cancer Res 61: 1527-1532, 2001

10. Neshat MS, Mellinghoff IK, Tran C, Stiles B, Thomas G, Petersen R, Frost P, Gibbons JJ, Wu H, Sawyers CL, Podsypanina K, Lee RT, Politis C, Hennessy I, Crane A, Puc J, Neshat M, Wang H, Yang L, Gibbons J, Dreisbach V, Blenis J, Gaciong Z, Fisher P, Sawyers C, Hedrick-Ellenson L, Parsons R: Enhanced sensitivity of PTEN-deficient tumors to inhibition of FRAP/mTOR An inhibitor of mTOR reduces neoplasia and normalizes p70/S6 kinase activity in Pten \pm mice. Proc Natl Acad Sci USA 98: 10314-10319, 2001

11. Podsypanina K, Lee RT, Politis C, Hennessy I, Crane A, Puc J, Neshat M, Wang H, Yang L, Gibbons J, Frost P, Dreisbach V, Blenis J, Gaciong Z, Fisher P, Sawyers C, Hedrick-Ellenson L, Parsons R: An inhibitor of mTOR reduces neoplasia and normalizes p70/S6 kinase activity in Pten \pm mice. Proc Natl Acad Sci USA 98: 10320-10325, 2001

12. Huang S, Houghton PJ: Targeting mTOR signaling for cancer therapy. Curr Opin Pharmacol 3: 371-377, 2003

13. Macdonald DR, Cascino TL, Schold SC, Jr., Cairncross JG: Response criteria for phase II studies of supratentorial malignant glioma. J Clin Oncol 8: 1277-1280, 1990

14. Powis G, Bonjouklian R, Berggren MM, Gallegos A, Abraham R, Ashendel C, Zalkow L, Matter WF, Dodge J, Grindey G, Vlahos CJ: Wortmannin, a potent and selective inhibitor of phosphatidylinositol-3-kinase. Cancer Res 54: 2419_ 2423, 1994

15. Vlahos CJ, Matter WF, Hui KY, Brown RF: A specific inhibitor of phosphatidylinositol 3-kinase, 2-(4-morpholinyl)-8-phenyl4H-1-benzopyran-4-one (LY294002). J Biol Chem 269: 52415248, 1994

16. Beuvink I, O'Reilly T, Zumstein S, Zilbermann F, Sedrani R, Kozma S, Thomas G, Lans H: Antitumor activity of RAD001, 
an orally active rapamycin derivative. Proceedings of American Association of Cancer Research 42: 366, 2001

17. Chang SM, Kuhn JG, Rizzo J, Robins HI, Schold SC, Jr., Spence AM, Berger MS, Mehta MP, Bozik ME, Pollack I, Gilbert M, Fulton D, Rankin C, Malec M, Prados MD: Phase I study of paclitaxel in patients with recurrent malignant glioma: A North American Brain Tumor Consortium report. J Clin Oncol 16: 2188-2194, 1998

18. Prados M, Kuhn J, Yung W, Robins H, Fink K, Greenberg H, Junck L, Cloughesy T, Chang S, Fine H, Schiff D, Nicholas M: A phase I study of CPT-11 given every 3 weeks to patients with recurrent malignant glioma. A North American Consortium study. Proc Am Soc Clin Oncol 19: 162,a, 2000

19. Cloughesy T, Kuhn J, Wen P, Chang S, Schiff D, Greenberg H, Junck L, Robins I, De Angelis L, Raizer J, Hess K, Prados M: Phase II trial of R115777 (Zarnestra) in patients with recurrent glioma not taking enzyme-inducing antiepileptic drugs (EIAED): A North American Brain Tumor Consortium (NABTC) report. Proc Am Soc Clin Oncol 21: 80a, 2002

20. Raymond E, Alexandre J, Depenbrock H, Mekhaldi S, Angevin E, Hanauske A, Baudin E, Escudier B, Frisch J, Boni J, Armand JP: CCI-779: A rapamycin analog with antitumor activity: A phase I study utilizing a weekly schedule (Abstract). Proc Am Soc Clin Oncol 19: 187a, 2000

21. Atkins MB, Hidalgo M, Stadler W, Logan T, Dutcher JP, Hudes G, Park Y, Marshall B, Boni J, Dukart G: A randomized double-blind phase II study of intravenous CCI-779 administrated weekly to patients with advanced renal cell carcinoma (Abstract). Proc Am Soc Clin Oncol 21: 10a, 2002

22. Chan S, Johnston S, Scheulen ME, Mross K, Morant R, Lahr A, Feussner A, Berger M, Kirsch T: First report: A phase 2 study of the safety and activity of CCI-779 for patients with locally advanced or metastatic breast cancer failing prior chemotherapy (Abstract). Proc Am Soc Clin Oncol 21: 44a, 2002

23. Brattstrom C, Sawe J, Jansson B, Lonnebo A, Nordin J, Zimmerman JJ, Burke JT, Groth CG: Pharmacokinetics and safety of single oral doses of sirolimus (rapamycin) in healthy male volunteers. Ther Drug Monit 22: 537-544, 2000

24. Eshleman JS, Carlson BL, Mladek AC, Kastner BD, Shide KL, Sarkaria JN: Inhibition of the mammalian target of rapamycin sensitizes U87 xenografts to fractionated radiation therapy. Cancer Res 62: 7291-7297, 2002

25. Peralba JM, DeGraffenried L, Friedrichs W, Fulcher L, Grunwald V, Weiss G, Hidalgo M: Pharmacodynamic evaluation of CCI-779, an inhibitor of mTOR, in cancer patients. Clin Cancer Res 9: 2887-2892, 2003

Address for offprints: Susan M. Chang, Neuro-Oncology Service, University of California, San Francisco, 400 Parnassus Ave, A808, San Francisco, CA 94143, USA. Tel.: 415353 2966; Fax: 415353 2167; E-mail: changs@ neurosurg.ucsf.edu 